SAINTIFIK, Vol.5, No.1, Januari 2019, pp. 44 52

ISSN 2407-4098 (print)

ISSN 2622-8904 (online)

\title{
Pengaruh Penerapan Model Pembelajaran Kooperatif Tipe Quick On The Draw terhadap Peningkatan Hasil Belajar Matematika Siswa
}

\author{
Marniati*1 $^{1}$ Tahir $^{2}$ \\ ${ }^{1,2}$ Universitas Sembilanbelas November Kolaka \\ e-mail:"11bungaitb@gmail.com; ${ }^{2}$ tahir.anwar.ta89@gmail.com
}

\begin{abstract}
Abstrak
Tujuan dari penelitian ini adalah untuk mengetahui perbedaan peningkatan hasil belajar matematika siswaantara siswa yang belajar menggunakan model pembelajaran kooperatif tipe quick on the draw dengan siswa yang belajar menggunakan model pembelajaran konvensional. Penelitian ini merupakan penelitian eksperimen yang bertujuan untuk mencari pengaruh perlakuan tertentu terhadap yang lain dalam kondisi yang terkontrol. Hasil penelitian diuji menggunakan uji hipotesis untuk mengetahui adanya perbedaan hasil belajar siswa antara siswa yang belajar menggunakan model pembelajaran kooperatif tipe quick on the draw dengan siswa yang belajar menggunakan model pembelajaran konvensional. Selain itu juga digunakan analisis statistik deskriptif untuk melihat perubahan sebelum dan sesudah perlakuan. Dari hasil penelitian menggunakan uji hipotesis dan analisis statistik deskriptif menunjukkan bahwa terdapat perbedaan peningkatan hasil belajar siswa yang belajar menggunakan model pembelajaran kooperatif tipe quick on the draw dengan siswa yang diajar dengan menggunakan model pembelajaran konvensional. Model pembelajaran kooperatif tipe quick on the draw dapat meningkatkan kemampuan belajar siswa sehingga terdapat perbedaan yang cukup signifikan antara kelompok siswa yang belajar menggunakan model pembelajaran kooperatif tipe quick on the draw dan kelompok siswa yang belajar dengan pembelajaran konvensional.
\end{abstract}

Kata kunci: Kooperatif, Quick on the draw

\section{PENDAHULUAN}

Pendidikan merupakan suatu hal yang sangat penting dan tidak dapat dipisahkan dari kehidupan seseorang, baik dalam keluarga, masyarakat, maupun bangsa. Salah satu tujuan pendidikan yang harus diperjuangkan oleh bangsa Indonesia adalah mencerdaskan kehidupan bangsa melalui pendidikan nasional. Negara Indonesia sebagai negara berkembang membutuhkan sumber daya manusia yang berkualitas. Salah satu usaha menciptakan sumber daya manusia yang berkualitas adalah melalui pendidikan. Sekolah sebagai salah satu lembaga pendidikan formal memiliki peranan yang sangat penting dalam mewujudkan tujuan pendidikan nasional melalui proses belajar mengajar.

Mengajar dan belajar merupakan proses kegiatan yang tidak dapat dipisahkan. Proses kegiatan tersebut sangat dipengaruhi oleh faktor-faktor yang sangat menentukan keberhasilan siswa. Meskipun diakui pendidikan adalah investasi jangka panjang yang harus ditata, tetapi pada kenyataannya Indonesia masih mengalami berbagai permasalahan, hal ini dalam bidang pendidikan khususnya matematika.

Matematika merupakan salah satu mata pelajaran yang penting dalam meningkatkan kemampuan intelektual siswa. Dengan belajar matematika, maka siswa dapat berpikir kritis, terampil berhitung, memiliki kemampuan mengaplikasikan konsep-konsep dasar matematika

Received December $1^{\text {st }}, 2018$; Revised December $6^{\text {th }}, 2018$; Accepted December 20 ${ }^{\text {th }}, 2018$ 
pada pelajaran lain maupun pada matematika itu sendiri dan dalam kehidupannya sehari-hari. Kurangnya keterlibatan siswa dalam kegiatan belajar mengajar, karena pembelajaran yang cenderung berpusat pada guru, menjadi penyebab dari rendahnya respon siswa terhadap pembelajaran matematika, jika siswa dapat diikut sertakan dalam pembelajaran, maka setidaknya dapat merubah pandangan matematika yang terkesan menakutkan dengan demikian pembelajaran akan lebih hidup dan akan timbal balik antara guru dan siswa, sehingga rasa senang terhadap matematika dapat mulai ditanamkan.

Keberhasilan proses belajar mengajar sangat ditentukan oleh peran guru sebagai sutradara dalam kelas. Oleh karena itu, pemilihan strategi, metode, atau model pembelajaran yang akan digunakan adalah sesuatu hal yang sangat penting. Berdasakan pengamatan penulis selama melakukan observasi di SMP Negeri 2 Ladongi dalam proses pembelajaran matematika, rendahnya hasil belajar siswa disebabkan oleh cara guru yang cenderung bersifat monoton, siswa hanya menerima informasi yang telah diberikan oleh guru. Akibatnya, siswa tidak dapat mengembangkan pengetahuannya secara mandiri serta membuat siswa kurang aktif dan merasa jenuh. Metode yang digunakan sudah bagus, namun kurangnya variasi pembelajaran menyebabkan kurangnya penguasaan materi dan pencapaian hasil masih jauh dari yang diharapkan. Hasil belajar matematika siswa masih kurang meningkat dari tahun ke tahun seperti tampak pada diagram berikut :

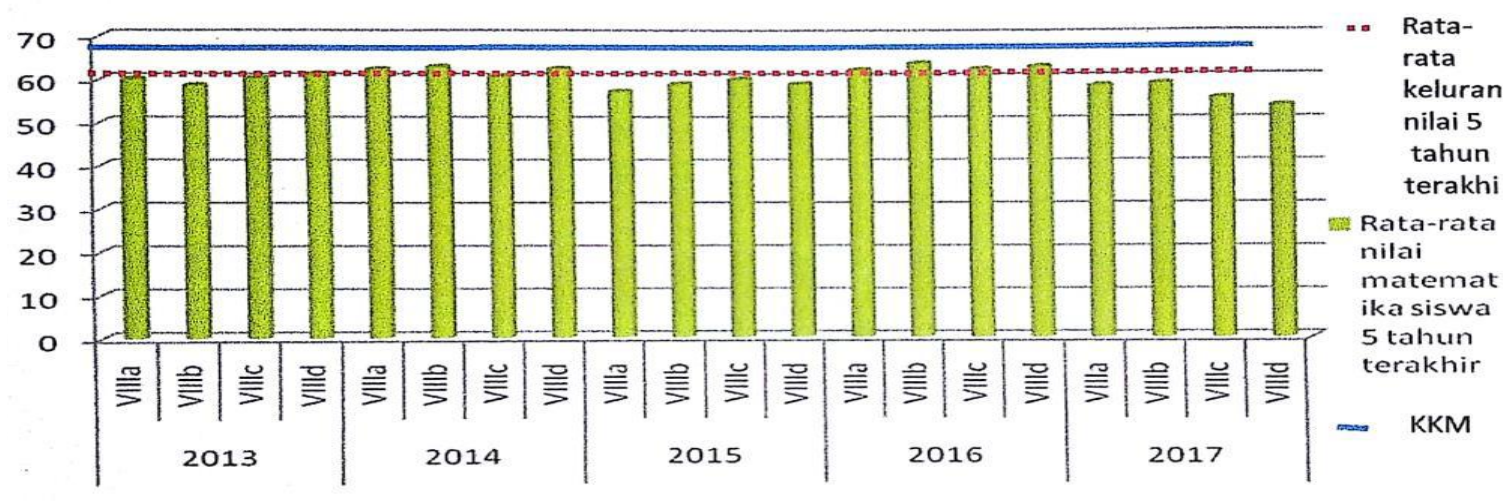

Diagram 1 Hasil belajar matematika siswa kelas VIII 5 tahun terakhir

Berdasarkan diagram di atas dapat dilihat selama 5 tahun terakhir rata-rata nilai siswa SMP Negeri 2 Ladongi adalah 60,19 kurang dari 68 yang merupakan KKM mata pelajaran matematika. Hal ini menandakan bahwa pembelajaran matematika disekolah tersebut masih belum optimal, ini disebabkan karena siswa masih kesulitan dalam belajar matematika, dan model pembelajaran yang diterapkan guru yang monoton dalam hal ini menerapkan model konvensional, sehingga membuat siswa kurang tertarik sehingga hasil belajar matematikanya tidak meningkat. Salah satu model pembelajaran yang dapat diterapkan dalam mencapai hasil belajar matematika yang lebih baik adalah model pembelajaran kooperatif. Dimana model pembelajaran kooperatif secara teoritik dipandang mampu mengembangkan bukan saja capaian akademik, tetapi juga non akademik seperti hubungan interpersonal dan kerja sama kelompok Rusman (2016). Terdapat banyak model pembelajaran kooperatif, salah satunya adalah quick on the draw.

Quick On The Draw dapat mendorong aktivitas belajar kelompok agar lebih efektif. Hal ini sejalan dengan pendapat Aisyiyah (2013) bahwa semakin efisien kerja kelompok, semakin cepat kemajuannya. Model ini memberikan pengalaman mengenai macam-macam keterampilan membaca dan membiasakan diri untuk belajar mandiri menggunakan bahan atau sumber yang telah diberikan. Quick On The Draw ini telah diterapkan oleh Paul Ginnis dan juga beberapa guru di sekolah yang menggunakan model ini dalam proses pembelajaran. Dalam hasil proses mengajarnya, siswa tidak hanya dapat meningkatkan prestasi belajarnya tetapi juga dapat meningkatkan kinerja dengan pengembangan pemahaman tentang belajar. Pada model ini siswa 
diharapkan dapat bekerjasama dengan anggota kelompoknya masing-masing dan dapat memunculkan sendiri pemahaman tentang materi yang diajarkan, karena proses pembelajaran berpusat pada siswa bukan guru.

Berikut ini merupakan kelebihan-kelebihan dari penggunaan teknik Quick On The Draw menurut Ginnis (Aisyiyah, 2013) : (1) Aktivitas ini mendorong kerja kelompok. Semakin efisien kerja kelompok, semakin cepat kemajuannya. Kelompok dapat belajar bahwa pembagian tugas lebih produktif daripada menduplikasi tugas. (2) Memberi pengalaman tentang macammacam keterampilan membaca, yang didorong oleh kecepatan aktivitas, ditambah belajar mandiri dan kecakapan ujian yang lain, seperti membaca pertanyaan dengan hati-hati, menjawab pertanyaan dengan tepat, membedakan materi yang penting dan yang tidak. (3) Kegiatan ini membantu siswa untuk membiasakan diri untuk belajar pada sumber, bukan hanya dari penejelasan guru. (4) Sesuai bagi siswa yang tidak dapat duduk diam.

Berdasarkan latar belakang di atas maka tujuan dari penelitian ini adalah untuk mengetahui perbedaan peningkatan hasil belajar matematika siswa yang diajar dengan menggunakan model pembelajaran kooperatif tipe quick on the draw dengan siswa yang diajar dengan model pembelajaran konvensional.

\section{METODE PENELITIAN}

\subsection{Jenis Penelitian}

penelitian ini adalah penelitian eksperimen dimana jenis yang dipilih adalah quasi eksperimen. Pada penelitian ini melibatkan dua kelas yaitu kelas eksperimen dan kelas kontrol. Kelas eksperimen diberi perlakuan dengan menggunakan model pembelajaran Kooperatif tipe Quick On The Draw dan pada kelas kontrol menggunakan pembelajaran konvensional sebagaimana biasanya. Adapun desain penelitiannya adalah non equivalen control group design dimana pada awal dan akhir pembelajaran kedua kelas di beri tes.

Subjek penelitian ini adalah siswa kelas VIII SMP Negeri 1 Ladongi yang berjumlah 91 siswa yang tebagi dalam 4 kelas. Pemelihan kelas eksperiman dan kelas kontrol dilakukan berdasarkan pertimbangan peneliti, yaitu dengan melihat hasil belajar matematika keempat kelas pada tahun terakhir.

\subsection{Metode Pengumpulan Data}

\subsubsection{Tes}

Tes diberikan kepada siswa pada akhir perlakuan. Digunakan untuk mengetahui kemampuan pemecahan masalah matematika siswa. Instrumen yang digunakan berupa Soal tes dimana soal yang digunakan adalah soal-soal matematika yang sebelumnya telah diuji valid dan reliabel serta diperhatikan tingkat kesukaran dan daya pembedanya.

\subsubsection{Observasi}

Observasi digunakan untuk memperoleh informasi terkait dengan aktivitas siswa selama proses pembelajaran berlangsung dan aktivitas guru dalam mengelola kelas. Instrumen yang digunakan berupa lembar observasi. lembar observasi digunakan untuk mengetahui bagaimana aktivitas siswa selama pembelajaran berlangsung dan aktivitas guru dalam mengelola kelas baik pada kelas eksperimen maupun kelas kontrol.

\subsection{Metode Analisis Data}

Untuk mendeskripsikan atau menggambarkan data penelitian dihitung mean, median, modus, rang, varians dan standar deviasi. Sedangkan untuk melihat peningkatan hasil belajar masing-masing kelas, maka dihitung $\mathrm{N}$-Gain dari kedua kelas dengan rumus.

SAINTIFIK Vol. 5, No. 1, Januari 2019: 44-52 


$$
g=\frac{S_{\text {postest }}-S_{\text {pretest }}}{S_{\text {maksimum }}-S_{\text {pretest }}} \quad \text { (Sundayana, 2015) }
$$

Selanjutnya nilai gain yang diperoleh diklasifikasikan sesuai klasifikasi berikut.

Tabel 1 Klasifikasi N - Gain

\begin{tabular}{|c|l|}
\hline $\mathrm{N}-$ Gain & Klasifikasi \\
\hline $\mathrm{g} \geq 0,7$ & Tinggi \\
\hline $0,3 \leq \mathrm{g}<0,7$ & Sedang \\
\hline $0<\mathrm{g}<0,3$ & Rendah \\
\hline $\mathrm{g}=0$ & Tidak meningkat \\
\hline $\mathrm{g}<0$ & Menurun \\
\hline
\end{tabular}

Untuk melihat perbedaan peningkatan hasil belajar pada kelas kontrol dan kelas eksperimen digunakan uji t dengan rumus.

$$
t=\frac{\left(\bar{X}_{1}-\bar{X}_{2}\right)}{\sqrt{\frac{\left(n_{1}-1\right) s_{1}^{2}+\left(n_{1}-1\right) s_{2}^{2}}{n_{1}+n_{2}-2}\left(\frac{1}{n_{1}}+\frac{1}{n_{2}}\right)}}
$$

(sugiyono, 2016)

yang mana sebelumnya data diuji normal menggunakan uji normalitas kolmogorov smirnov dan dan homogenitas menggunakan uji F.

Adapun hipotesis yang digunakandalam penelitian ini adalah sebagai berikut.

H0: Tidak terdapat perbedaan peningkatan hasil belajar antara siswa yang belajar menggunakan model pembelajaran kooperatif tipe quick on the draw dengan siswa yang belajar menggunakan model pembelajaran konvensional.

H1: terdapat perbedaan peningkatan hasil belajar antara siswa yang belajar menggunakan model pembelajaran kooperatif tipe quick on the draw dengan siswa yang belajar menggunakan model pembelajaran konvensional.

\section{HASIL DAN PEMBAHASAN}

Penelitian ini dilaksanakan pada Tanggal 27 April 2018 sampai 12 Mei 2018 di kelas VIII SMP Negeri 2 Ladongi Semester Genap Tahun Ajaran 2017/2018. Peneliti menggunakan dua kelas yaitu kelas VIIID sebagai kelas eksperimen dan kelas VIIIC sebagai kelas kontrol. Penelitian ini dilakukan sebanyak 6 pertemuan yang terdiri dari pretest pada pertemuan 1 , pemberian perlakuan pada pertemuan 2 hingga pertemuan 5, dan posttest pada pertemuan 6 . Pretest diberikan pada awal pertemuan, sedangkan posttest diberikan pada akhir pertemuan. Adapun materi yang diajarkan di kedua kelas pada penelitian ini adalah kubus dan balok.

\subsection{Data Pretest Hasil Belajar Matematika Siswa}

Pretest diberikan sebelum siswa mendapatkan perlakuan berupa penerapan metode pembelajaran guided inquiry untuk kelas eksperimen dan pembelajaran konvensional untuk 
kelas kontrol. Pretest ini bertujuan untuk melihat gambaran kemampuan awal masing-masing kelas. Gambaran umum hasil pretest tersebut disajikan pada Tabel 2.

Tabel 2 Analisis Deskriptif Data Pretest

\begin{tabular}{|c|c|c|}
\hline $\begin{array}{c}\text { Statistik } \\
\text { Deskriptif }\end{array}$ & $\begin{array}{c}\text { Kelas } \\
\text { Eksperimen }\end{array}$ & $\begin{array}{c}\text { Kelas } \\
\text { Kontrol }\end{array}$ \\
\hline Banyak Data & 24 & 22 \\
\hline Nilai Terendah & 40 & 40 \\
\hline Nilai Tertinggi & 90 & 90 \\
\hline Range & 50,00 & 50 \\
\hline Rata-rata & 56,04 & 56,59 \\
\hline Modus & 50 & 60 \\
\hline Median & 50,00 & 57,5 \\
\hline Varians & 171,69 & 191,40 \\
\hline Standar Deviasi & 13,10 & 13,83 \\
\hline
\end{tabular}

\subsection{Data Posttest Hasil Belajar Matematika Siswa}

Data posttest menunjukkan hasil belajar matematika siswa pada materi kubus dan balok setelah dilakukannya proses pembelajaran. Gambaran umum hasil posttest tersebut disajikan pada Tabel 3 .

Tabel 3 Analisis Deskriptif Data Posttest

\begin{tabular}{|c|c|c|}
\hline $\begin{array}{c}\text { Statistik } \\
\text { Deskriptif }\end{array}$ & $\begin{array}{c}\text { Kelas } \\
\text { Eksperimen }\end{array}$ & $\begin{array}{c}\text { Kelas } \\
\text { Kontrol }\end{array}$ \\
\hline Banyak Data & 24 & 22 \\
\hline Nilai Terendah & 58 & 55 \\
\hline Nilai Tertinggi & 95 & 91 \\
\hline Range & 37 & 36 \\
\hline Rata-rata & 76,21 & 70,68 \\
\hline Modus & 80 & 70 \\
\hline Median & 78 & 70 \\
\hline Varians & 80,95 & 56,89 \\
\hline Standar Deviasi & 9,00 & 7,54 \\
\hline
\end{tabular}

\subsection{Data Peningkatan Hasil Belajar Matematika Siswa}

Berdasarkan data pretest dan posttest yang telah diperoleh, selanjutnya dilakukan perhitungan nilai N-Gain. Perhitungan ini digunakan untuk mengetahui besar peningkatan hasil belajar siswa. Gambaran umum hasil perhitungan N-Gain disajikan pada tabel 4.

Tabel 4 Analisis Deskriptif Data N-Gain

\begin{tabular}{|c|c|c|}
\hline $\begin{array}{c}\text { Statistik } \\
\text { Deskriptif }\end{array}$ & $\begin{array}{c}\text { Kelas } \\
\text { Eksperimen }\end{array}$ & $\begin{array}{c}\text { Kelas } \\
\text { Kontrol }\end{array}$ \\
\hline banyak data & 24 & 22 \\
\hline nilai terendah & 0,2 & 0,1 \\
\hline nilai tertinggi & 0,67 & 0,47 \\
\hline
\end{tabular}




\begin{tabular}{|c|c|c|}
\hline $\begin{array}{c}\text { Statistik } \\
\text { Deskriptif }\end{array}$ & $\begin{array}{c}\text { Kelas } \\
\text { Eksperimen }\end{array}$ & $\begin{array}{c}\text { Kelas } \\
\text { Kontrol }\end{array}$ \\
\hline range & 0,47 & 0,37 \\
\hline rata-rata & 0,46 & 0,30 \\
\hline modus & 0,5 & 0,25 \\
\hline median & 0,5 & 0,25 \\
\hline varians & 0,01 & 0,01 \\
\hline standar deviasi & 0,10 & 0,11 \\
\hline
\end{tabular}

Selanjutnya, peningkatan hasil belajar matematika siswa diklasifikasikan seperti tampak pada diagram 2.

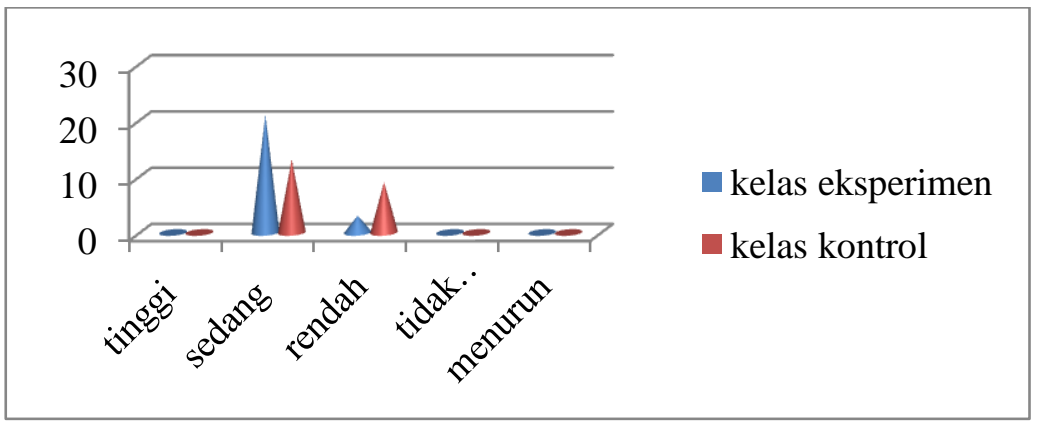

Digram 2 Klasifikasi nilai N-Gain

\subsection{Analisis Lembar Observasi Guru}

Lembar observasi guru digunakan untuk melihat, apakah guru dapat melaksanakan proses pembelajaran sesuai dengan sintaks yang ada dalam model pembelajaran kooperatif tipe Quick On The Draw dan model Pembelajaran Konvensional. Hasil lembar observasi tersebut disajikan pada diagram berikut berikut.

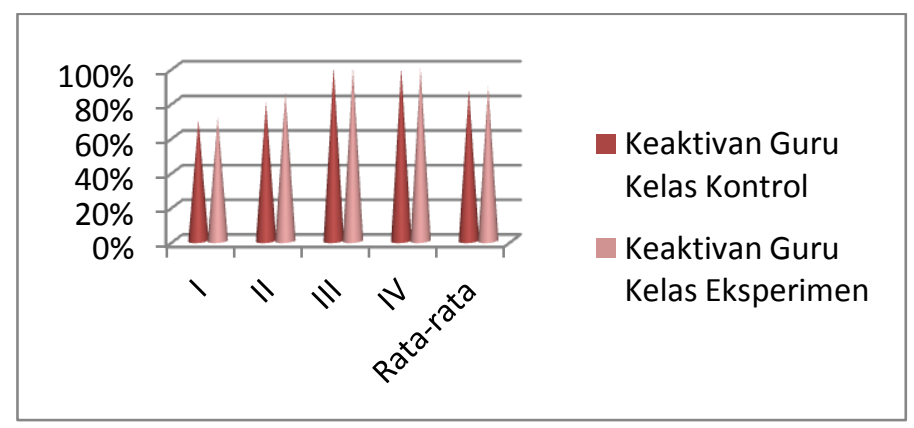

Diagram 3 Hasil Analisi Lembar Observasi Guru

Dari hasil analisis lembar observasi guru pada diagram 3, terlihat bahwa peresentase nilai rata-rata aktivitas guru dalam proses pembelajaran menggunakan model pembelajaran kooperatif tipe Quick On The Draw adalah $89,28 \%$ berada pada kategori sangat aktif dan ratarata keaktivan guru pada kelas dengan model pembelajaran konvensional $87,5 \%$ berada pada kategori sangat aktif.

\subsection{Analisis Lembar Observasi Aktivitas Siswa}


Lembar penilaian aktivitas siswa digunakan untuk melihat keaktivan siswa selama proses pembelajaran berlangsung. Hasil lembar observasi tersebut disajikan pada diagram berikut berikut

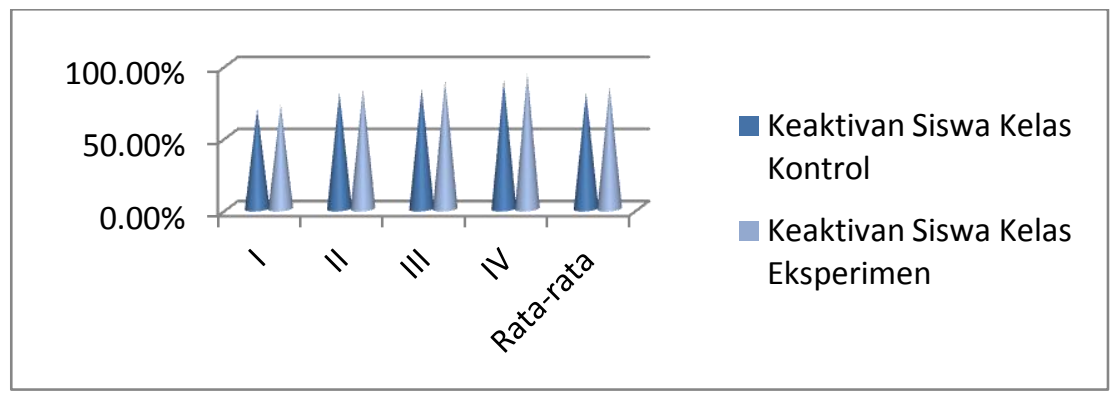

Diagram 4. Hasil Analisi embar Observasi Siswa

Dari hasil analisis pada diagram 4, terlihat bahwa peresentase nilai rata-rata aktivitas siswa dalam proses pembelajaran menggunakan model pembelajaran kooperatif tipe Quick On The Draw sebesar $84,72 \%$ berada pada kategori sangat aktif dan rata-rata aktivitas siswa dalam proses pembelajaran menggunakan metode konvensional sebesar $80,6 \%$ berada pada kategori sangat aktif.

\subsection{Analisis Inferensial}

Untuk menjawab tujuan peneletian maka dilakukan analisis inferensial pada data peningkatan hasil belajar siswa (N-Gain). Dimulai dengan Uji normalitas data pada kelas eksperimen dan kelas kontrol. Berdasarkan uji yang telah dilakukan pada taraf signifikansi $\alpha=5 \%$ diperoleh hasil pada tabel 5 berikut.

Tabel 5 Uji Normalitas Data

\begin{tabular}{|l|c|c|c|}
\hline $\begin{array}{l}\text { Uji } \\
\text { Normalitas }\end{array}$ & $\mathrm{D}_{\text {hit }}$ & $\mathrm{D}_{\text {tab }}$ & kesimpulan \\
\hline $\begin{array}{l}\text { kelas } \\
\text { eksperimen }\end{array}$ & 0,229 & 0,278 & Normal \\
\hline kelas kontrol & 0,199 & 0,290 & Normal \\
\hline
\end{tabular}

Dari tabel 5, diperoleh bahwa data kedua kelompok berdistribusi normal, selajutnya dilakukan uji homogenitas untuk melihat kesamaan varians kedua kelompok dan diperoleh hasil $F_{\text {hitung }}=0,812$ dan $F_{\text {tabel }}=2,38$. Karena $F_{\text {hitung }}<F_{\text {tabel }}(0,812<2,38)$ maka dapat disimpulkan data memiliki varians yang sama atau homogen

Berdasarkan uji prasyarat yang dilakukan, diperoleh hasil data berdistribusi normal dan homogen maka pengujian hipotesis menggunakan t-test Polled Varian . Berdasarkan hasil analisis uji hipotesis dengan menggunakan uji $\mathrm{t}$ diperoleh $t=4,53$ dan $t_{\text {tabel }}(\alpha=0,05 ; d k=44)=2,02$. Karena $t_{\text {hitung }}>t_{\text {tabel }}(4,53>2,015)$ maka $\mathrm{H}_{0}$ ditolak dengan kata lain terdapat perbedaan rata-rata peningkatan hasil belajar matematika antara kelas kontrol dan kelas eksperimen.

Jika dilihat dari rata-rata nilai siswa sebelum dilakukan pelakuan tampak bahwa nilai kelas eksperimen dan kelas kontrol relatif sama yaitu 56,04 dan 56,59. Setelah diberikan 
perlakuan diperoleh nilai rata-rata kelas eksperimen sebesar 76,21 dan kelas kontrol 70,68, sehingga jika dilihat dari rata-rata peningkatan kelas eksperimen sebesar 0,46 yang masuk pada kategori sedang sedangkan rata-rata peningkatan kelas kontrol 0,30 yang berada pada kategori rendah. Dari hasil uji hipotesis menunjukkan hal yang sama, bahwa hasil belajar siswa yang mengikuti pembelajaran dengan model pembelajaran kooperatif tipe quick on the draw lebih baik daripada siswa yang mengikuti pembelajaran dengan model pembelajaran konvensional. Adanya perbedaan peningkatan hasil belajar matematika tersebut dikarenakan pembelajaran kooperatif sebagai metode pengajaran dimana siswa bekerja sama dalam kelompok-kelompok kecil untuk saling membantu mempelajari isi akademik. Interaksi yang dilakukan siswa dalam pembelajaran kooperatif akan melatih siswa untuk bekerja sama, saling membantu, menghargai pendapat orang lain, dan percaya diri terhadap kemampuannya sehingga dapat meningkatkan sikap positif siswa terhadap matematika, yang kemudian berdampak pada hasil yang diperolehnya. Selain itu, hasil yang diperoleh tidak lepas dari kelebihan-kelebihan dari penggunaan teknik quick on the draw yang di ungkapkan oleh Ginnis yaitu teknik quick on the draw mendorong kerja kelompok. Semakin efisien kerja kelompok, semakin cepat kemajuannya. Selain itu, teknik quick on the draw membantu siswa untuk membiasakan diri untuk belajar pada sumber, bukan hanya dari penejelasan guru. Dari hasil penelitian ini menunjukkan bahwa pengaruh model pembelajaran kooperatif tipe quick on the draw dapat meningkatkan kemampuan belajar siswa sehingga terdapat perbedaan yang cukup signifikan antara kelompok siswa yang belajar menggunakan model pembelajaran kooperatif tipe quick on the draw dan kelompok siswa yang belajar dengan pembelajaran konvensional.

\section{KESIMPULAN}

Dari hasil penelitian menggunakan uji hipotesis dan analisis statistik deskriptif menunjukkan bahwa terdapat perbedaan peningkatan hasil belajar matematika siswa yang menggunakan model pembelajaran kooperatif tipe quick on the draw dan pembelajaran konvensional. Model pembelajaran kooperatif tipe quick on the draw dapat meningkatkan kemampuan belajar siswa sehingga terdapat perbedaan yang cukup signifikan antara kelompok siswa yang belajar menggunakan model pembelajaran kooperatif tipe quick on the draw dan kelompok siswa yang belajar dengan pembelajaran konvensional. Selanjutnya, berdasarkan hasil penelitian ini, dapat disampaikan beberapa saran terkait dengan penelitian selanjutnya tentang model pembelajaran kooperatif tipe quick on the draw bahwa perlu diteliti pula mengenai faktor-faktor yang mempengaruhi tingkat keberhasilan dari model pembelajaran kooperatif tipe quick on the draw sehingga dapat menjadi bahan pembelajaran bagi para guru dalam menerapkan model pembelajaran kooperatif tipe quick on the draw.

\section{DAFTAR PUSTAKA}

Aisyiyah, Nurhidayani. 2013. Keefektifan Teknik Quick On The Draw Terhadap Minat Dan Hasil Belajar Sumber Daya Alam Pada Siswa Kelas IV Di Sekolah Dasar Negeri. Semarang: UNNES. Tersedia di http://lib.unnes.ac.id (Diakses pada tanggal 15 Januari 2017 pukul 13.10).

Dantes, N. 2012. Metode Penelitian. Yogyakarta: Penerbit Andi

Rusman. 2016. Model-Model Pembelajaran. Jakarta: PT Raja GrafindoPersada.

Sugiyono, 2016. Satistika Untuk Penelitian. Bandung: Alfabeta

Sundayana, R. 2014. Statistika Penelitian Pendidikan. Bandung: Alfabeta

Suprijono. 2009. Cooperative Learning Teori \& Aplikasi Paikem. Yogyakarta: Pustaka Pelajar. 
Susanti, Eva. 2010. Penerapan Model Pembelajaran Kooperatif Tipe Quick On The Draw untuk Meningkatkan Motivasi Belajar Matematika Pada Materi Pecahan Murid Kelas III MI Muhammadiyah Simpang Kubu Kabupaten Kampar. Pekan Baru: Skripsi Universitas Islam Negeri Sultan Syarif Kasim Riau.

Sutikno. 2013. Belajardan Pembelajaran Upaya Kreatif dalam Mewujudkan Pembelajaran yang Berhasil. Lombok: Holistica 